University of Nebraska - Lincoln

DigitalCommons@University of Nebraska - Lincoln

Publications, Agencies and Staff of the U.S.

Department of Commerce

U.S. Department of Commerce

2011

Cooperative hunting behavior, prey selectivity and prey handling by pack ice killer whales (Orcinus orca), type B, in Antarctic Peninsula waters

\author{
Robert L. Pitman \\ National Oceanic and Atmospheric Administration, robert.pitman@noaa.gov \\ John W. Durban \\ National Oceanic and Atmospheric Administration
}

Follow this and additional works at: https://digitalcommons.unl.edu/usdeptcommercepub

Part of the Environmental Sciences Commons

Pitman, Robert L. and Durban, John W., "Cooperative hunting behavior, prey selectivity and prey handling by pack ice killer whales (Orcinus orca), type B, in Antarctic Peninsula waters" (2011). Publications, Agencies and Staff of the U.S. Department of Commerce. 306.

https://digitalcommons.unl.edu/usdeptcommercepub/306

This Article is brought to you for free and open access by the U.S. Department of Commerce at DigitalCommons@University of Nebraska - Lincoln. It has been accepted for inclusion in Publications, Agencies and Staff of the U.S. Department of Commerce by an authorized administrator of DigitalCommons@University of Nebraska - Lincoln. 
MARINE MAMMAL SCIENCE, $* *(*): * * * \_* * *(* * * 2011)$

2011 by the Society for Marine Mammalogy

Published 2011. This article is a US Government work and is in the public domain in the USA.

DOI: $10.1111 / \mathrm{j} .1748-7692.2010 .00453 . x$

\title{
Cooperative hunting behavior, prey selectivity and prey handling by pack ice killer whales (Orcinus orca), type B, in Antarctic Peninsula waters
}

\author{
ROBERT L. PITMAN \\ JOHN W. DURBan \\ Protected Resources Division, \\ Southwest Fisheries Science Center, \\ National Marine Fisheries Service, \\ National Oceanic and Atmospheric Administration, \\ 8604 La Jolla Shores Drive, \\ La Jolla, California 92037, U.S.A. \\ E-mail: robert.pitman@noaa.gov
}

\begin{abstract}
Currently, there are three recognized ecotypes (or species) of killer whales (Orcinus orca) in Antarctic waters, including type B, a putative prey specialist on seals, which we refer to as "pack ice killer whale" (PI killer whale). During January 2009, we spent a total of $75.4 \mathrm{~h}$ observing three different groups of PI killer whales hunting off the western Antarctic Peninsula. Observed prey taken included 16 seals and 1 Antarctic minke whale (Balaenoptera bonaerensis). Weddell seals (Leptonychotes weddellii) were taken almost exclusively (14/15 identified seal kills), despite the fact that they represented only $15 \%$ of 365 seals identified on ice floes; the whales entirely avoided taking crabeater seals (Lobodon carcinophaga; $82 \%$ relative abundance) and leopard seals (Hydrurga leptonyx; 3\%). Of the seals killed, the whales took 12/14 $(86 \%)$ off ice floes using a cooperative wave-washing behavior; they produced 120 waves during 22 separate attacks and successfully took 12/16 (75\%) of the Weddell seals attacked. The mean number of waves produced per successful attack was 4.1 (range 1-10) and the mean attack duration was 30.4 min (range 15-62). Seal remains that we examined from one of the kills provided evidence of meticulous postmortem prey processing perhaps best termed "butchering."
\end{abstract}

Key words: Antarctica, hunting behavior, killer whale, Leptonychotes weddellii, Orcinus orca, prey handling, prey specialization, Weddell seal.

Killer whales are fast-swimming, long-lived, intelligent, social animals and the largest apex predators in the ocean. Not surprisingly then, their predatory habits have been cited as a major force in shaping marine ecosystems. In higher latitudes, where they occur most commonly (Forney and Wade 2006), killer whales have been implicated in everything from the direct and cascading affects of cropping down (and perhaps endangering) prey populations (Guinet et al. 1992; Estes et al. 1998; 
Springer et al. 2003, 2008; Branch and Williams 2006; Ainley et al. 2007; Bolt et al. 2009; Estes et al. 2009), to being the primary impetus for the breeding migrations of large whales (Corkeron and Connor 1999, Connor and Corkeron 2001). These claims have generated a series of pointed rebuttals (e.g., Clapham 2001, DeMaster et al. 2006, Mizroch and Rice 2006, Mehta et al. 2007, Trites et al. 2007, Wade et al. 2007, Barbraud and Cotté 2008, Wade et al. 2009), and the only consensus that has emerged to date is that too little is known about killer whale feeding habits to gauge the degree to which they may be structuring marine communities (Williams et al. 2004, Ainley et al. 2010).

Three distinct forms of killer whales (Orcinus orca) have been described from Antarctic waters; referred to as types A, B, and C, they are purported prey specialists on Antarctic minke whales (Balaenoptera bonaerensis), seals, and fish, respectively (Pitman and Ensor 2003). Although their ranges overlap at sea, the three forms are phenotypically distinct and recent molecular genetics analyses have suggested that they represent separate species (LeDuc et al. 2008, Morin et al. 2010). In this paper we focus on the type B form, which commonly hunts among the pack ice in its pursuit of seals and we refer to it as "pack ice killer whale" (PI killer whale).

To date, generalizations about the prey of killer whales in Antarctica have been based solely on opportunistic observations - there have been no directed studies on their feeding habits or prey preferences. Reported prey of PI killer whales has included crabeater seals (Lobodon carcinophaga), Weddell seals (Leptonychotes weddellii), leopard seals (Hydrurga leptonyx) and southern elephant seals (Mirounga leonina; Pitman and Ensor 2003, Visser et al. 2008, Ainley et al. 2009). There are also unconfirmed reports of them "hunting" Antarctic minke whales and harassing humpback whales (Megaptera novaeangliae) in Antarctic waters, and both of these species have been considered potential prey species (Pitman and Ensor 2003). And recently, an apparently smaller form of PI killer whale was observed feeding on gentoo and chinstrap penguins (Pygoscelis papua and P. antarctica, respectively) in the Antarctic Peninsula (AP) area (Pitman and Durban 2010).

An apparently unique, cooperative hunting behavior by PI killer whales was first described by Smith et al. (1981) who reported that after a group of seven whales located a lone crabeater seal on an ice floe, the whales swam approximately $100 \mathrm{~m}$ away from it, then turned and swam rapidly toward the floe in echelon formation. They deliberately created a wave that broke up the floe and washed the seal into the water. The seal was not seen again and it was not known if it escaped or was killed and eaten. This remarkable wave-wash hunting behavior was not reported again until Visser et al. (2008) provided a detailed account of a group of seven PI killer whales that washed a crabeater seal off a floe several times before they killed and ate it. Visser et al. (2008) also compiled a list of all of the then-known observations of this behavior, which included attacks on five individual seals (three crabeaters, one leopard, and one Weddell) and an Adélie penguin (Pygoscelis adeliae). One might have inferred from this handful of records that wave-wash hunting by killer whales in Antarctica was an uncommon behavior.

Herein, we report on our observations of PI killer whales hunting off the west coast of the AP during January 2009. They hunted almost exclusively by wavewashing seals off ice floes, which provided us with a unique opportunity to study cooperative hunting behavior and prey choice by a mammal-eating killer whale. In addition to providing new details on wave-wash hunting behavior, we also describe and discuss our observations on prey selectivity and postmortem prey handling by this little-known killer whale. 

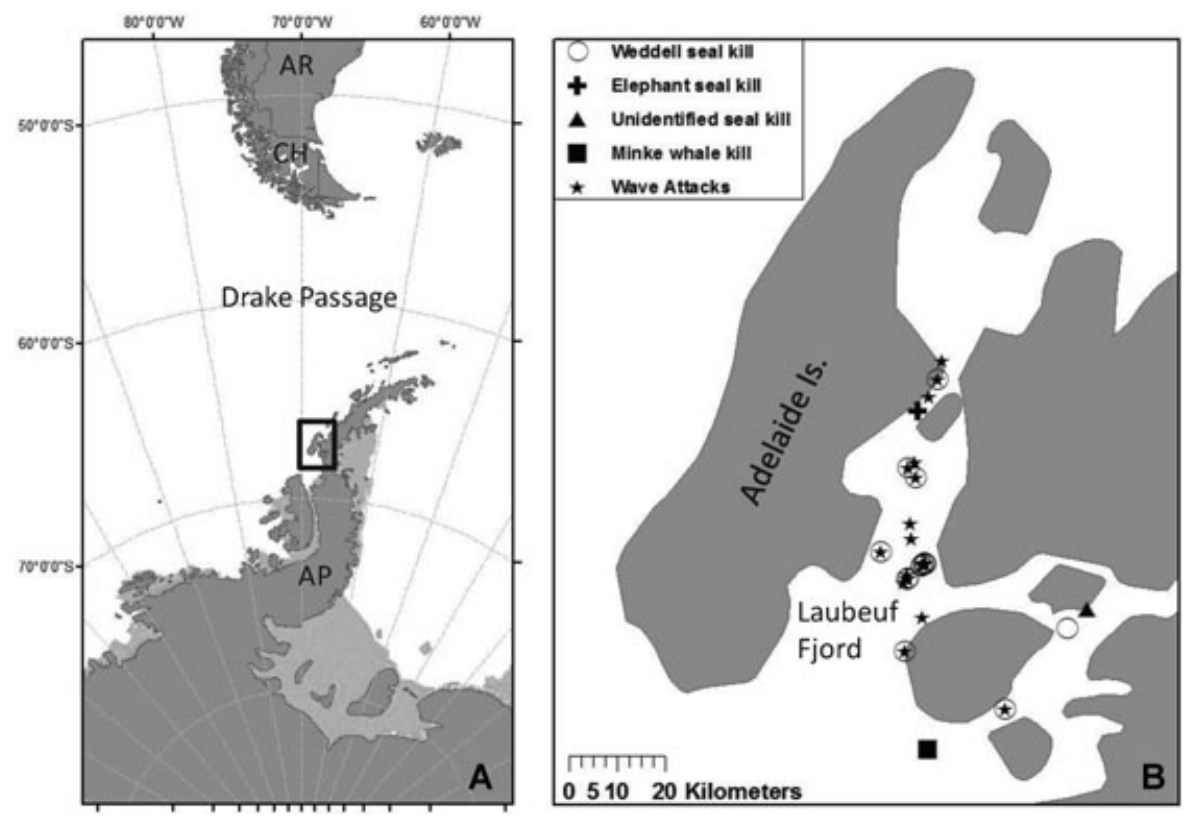

Figure 1. Study area: A. The southern tip of South America (Chile, CH; Argentina, AR) and the AP separated by the Drake Passage; the box indicates where we made our observations during 13-30 January 2009; B. Enlargement of the box showing Adelaide Island and Laubeuf Fjord, along with the location and species of prey taken by pack ice killer whales-Weddell seal $(n=14)$, southern elephant seal $(n=1)$, unidentified seal $(n=1)$, Antarctic minke whale $(n=1)$, and sites of all wave-wash attacks $(n=22)$.

\section{MATERIALS AND METHODS}

We made observations from the 19.5 m motor-sailing yacht Golden Fleece during 13-30 January 2009, in Laubeuf Fjord, east of Adelaide Island, off the west coast of the AP (Fig. 1). While there, we encountered 10\%-90\% cover of pack ice and "bergy bits" (i.e., house-sized or smaller chunks of floating glacial ice).

Observations were made outside, from the top of the wheelhouse, approximately $5 \mathrm{~m}$ above sea level, with 2-7 observers on watch at all times, weather permitting, using handheld, $7 \times 50 \mathrm{~mm}$ binoculars. Typically, once we located a group of whales we stayed with it until we lost it due to dense pack ice, bad weather, or darkness. To relocate animals and to track their movements, we deployed SPOT5 location-only satellite transmitters (Wildlife Computers, Redmond, WA) onto three animals from three different groups. The $41 \mathrm{~g}$ tags were deployed using crossbow bolts fired at the dorsal fins of whales, with tags held in place by two $6.5 \mathrm{~cm}$ barbed titanium darts (see Andrews et al. 2008 for additional details). Detailed results of our tagging efforts will be reported elsewhere.

We identified individual whales by comparing high-quality images ( $>10$ megapixel resolution) taken using digital SLR cameras and telephoto zoom lenses. Individual animals were identified by the presence of naturally acquired nicks in the dorsal fin, distinctive dorsal fin shape, and differences in saddle patch pigmentation (Ford et al. 2000). Time-annotated notes were taken during our focal follows 
with additional details gleaned from the time stamps and imagery recorded on the $>8,000$ digital photos that we acquired.

We assumed that our observations represented normal hunting behavior because the whales appeared to be largely oblivious to our presence and often hunted and fed within $100 \mathrm{~m}$ of our vessel. However, our observations were made in conjunction with a natural history film team that was interested in recording killer whale hunting behavior. On seven occasions they put a launch in the water to film the seals and whales, and the presence of the launch sometimes appeared to distract the whales. For example, the juveniles often seemed to be more interested in the launch than in participating in the hunt, which prolonged the hunting process. Therefore, when appropriate, we distinguished between observations made when the launch was in the water and when it was not.

To determine if hunting whales had preferences among the different species of seals that were present on the ice, we identified a random sample of 365 seals hauled out on floes as we motored through the pack ice in Laubeuf Fjord over three separate days with clear observation conditions. Only seals within approximately $100 \mathrm{~m}$ of the vessel were recorded to avoid any identification problems. When whales were hunting in the pack ice, they located seals on ice floes by "spy-hopping"-i.e., lifting their heads vertically out of the water in order to view things above the surface. We also recorded the number and species of seals that were detected by spy-hopping whales, noted whether or not there was a subsequent wave-wash attack, and whether or not the seal was killed and eaten. Killer whales often kill and consume their prey underwater, and it can be difficult to determine if a predation event has even occurred, but there are some useful clues. When the prey was not seen again, we assumed a kill had taken place only if we detected the fishy odor and oil slick at the surface that results when a marine mammal is dismembered under water; normally we also saw bits of tissue from the prey floating on the surface or birds feeding on resultant oil droplets or scraps (see section "Results").

\section{RESULTS}

Between 13 and 30 January 2009, we had 17 encounters with 6 different groups of PI (type B) killer whales off the western AP (Fig. 1A); this was the only ecotype/species of killer whale that we saw during the study. We followed individual groups ranging in size from 2 to 24 animals (median $=10)$ for a total of $88 \mathrm{~h}(5,290 \mathrm{~min})$ and photographically identified 63 individuals. However, most of our encounters (13/17), and all of our predation observations, involved three distinct, apparently stable, groups of 10, 4, and 7 animals (groups 1, 2, 3, respectively; Table 1) that we observed east of Adelaide Island (Fig. 1B). Although all three groups were not seen together in any single encounter, they were all connected by association, as group 2 cooperatively foraged with both groups 1 and 3 on occasion (Table 1). We followed one or more of these three groups for a total of $75.4 \mathrm{~h}$ (4,521 min) over $12 \mathrm{~d}(13-24$ January), and we spent an average of $407 \mathrm{~min}$ per encounter (range 140-867 min) on days when we were with the whales.

\section{Hunting Behavior}

Although there were miles of open water immediately outside Laubeuf Fjord, the whales, including the three groups that we satellite tracked, restricted nearly all of 


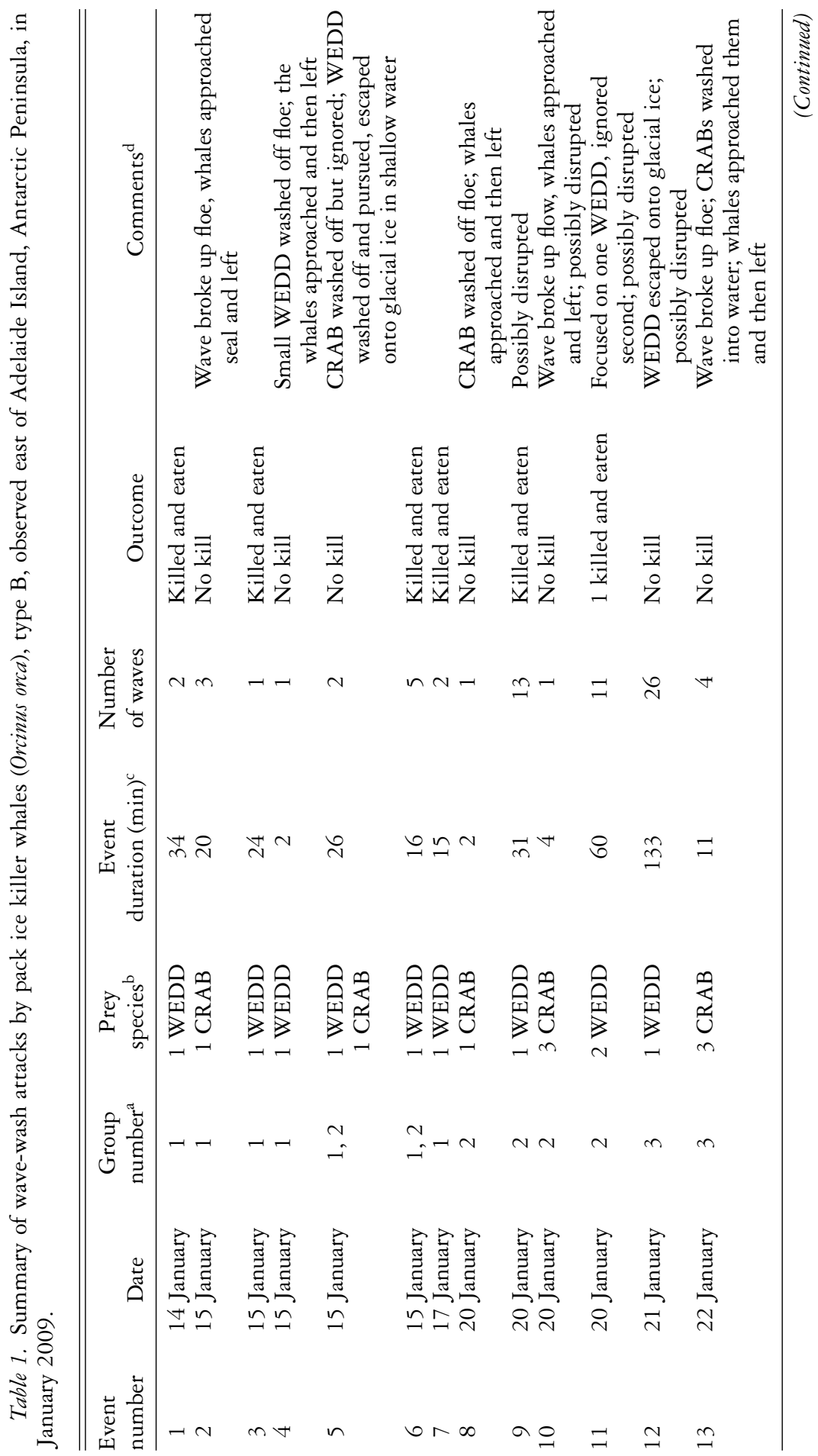




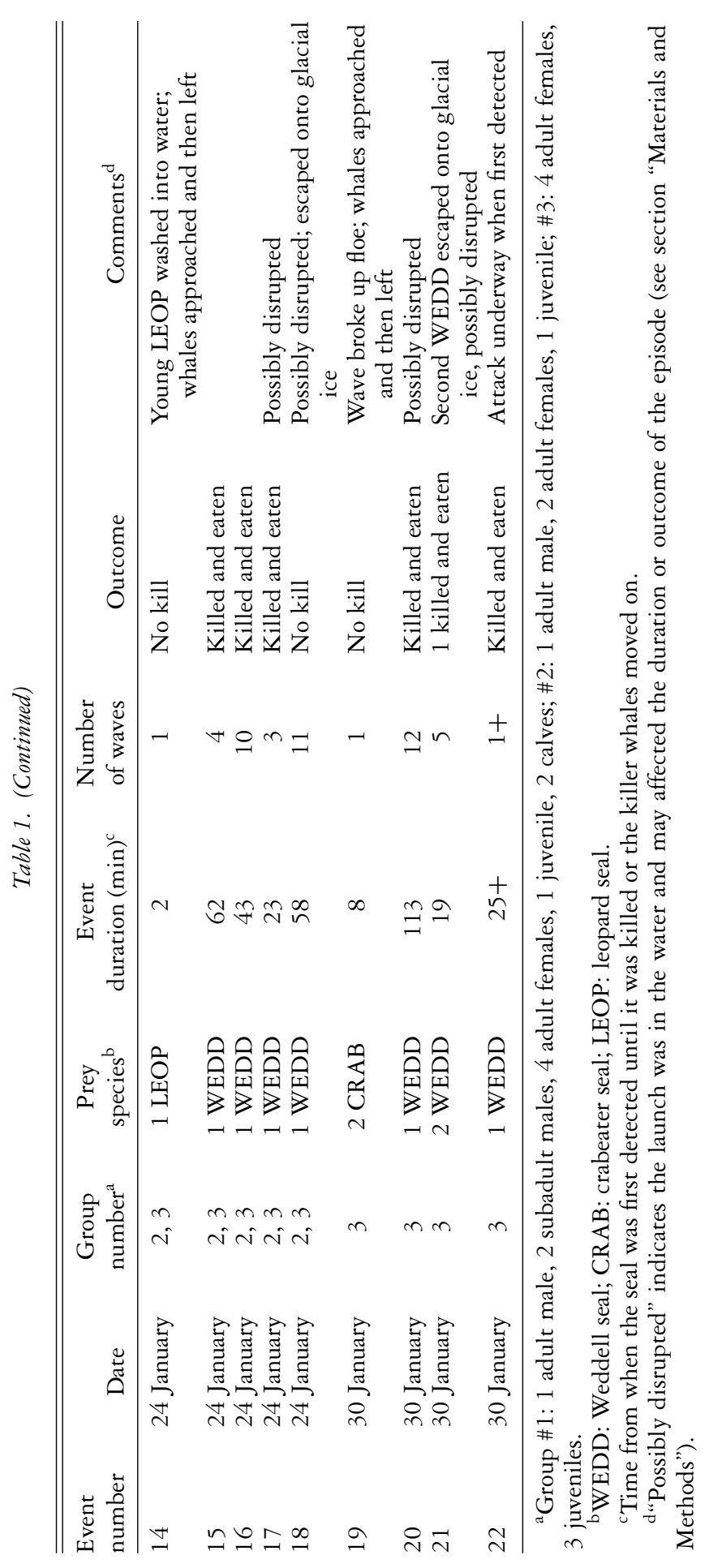


their hunting to the pack ice fields within the fjord. PI killer whales had two different travel modes depending on the amount of ice present. In open water with little or no ice, they usually formed a fairly tight group and traveled within two body lengths of each other, although scattered individuals (usually adult males) sometimes traveled $500 \mathrm{~m}$ or more away from the main group. In areas of pack ice, however, the group usually fanned out and traveled as individuals or cow/calf pairs. When that happened, all of the group members immediately began spy-hopping when they were adjacent to ice floes. They were looking for seals hauled out on the ice and when we were close to spy-hopping whales, we could see their wide-open eyes looking over the ice. For small floes without seals, whales usually spy-hopped just once and moved on, but for larger floes (e.g., length $>10 \mathrm{~m}$ ), whales spy-hopped several times as they made their way along the edge of the floe.

There were two different kinds of ice in the water, which had significance for both resting seals and hunting whales. Floes are formed from frozen seawater; they are, consequently, relatively flat, not very dense, and during our study ranged in size from $<1 \mathrm{~m}$ to $>200 \mathrm{~m}$ in length, although most were $<10 \mathrm{~m}$ long. First-year floe ice was usually $<1 \mathrm{~m}$ thick, while multi-year floes ranged from 1 to $3 \mathrm{~m}$ thick and stood higher out of the water. Seals almost always hauled out on low, flat floes, especially first-year ice, presumably because they were easier to access. The second type of ice came from calving glaciers; it included ice bergs and bergy bits and was comprised of snow compressed into very dense, hard ice. Because glacial ice was usually irregularly shaped, the seals avoided hauling out on it, but when they did, the whales had a difficult time detecting them and wave-washing them off it (see later).

When a spy-hopping whale detected a seal on the ice, it typically responded in one of two ways usually depending on the species of the seal (see section "Hunting Success and Prey Selectivity"). Initially, the whale began a series of spy-hops, sometimes taking 10 or more views of the seal from different locations around the edge of the floe. If a calf was present, it usually spy-hopped alongside its mother. After a minute or two, the whale(s) would either abruptly leave the seal and continue on to the next floe, or it would disappear for 15-30 s before surfacing again next to the same floe. In the latter case, we assumed that it went down to vocalize to other members of the group because usually in less than $1 \mathrm{~min}$, the rest of the group all surfaced next to the floe and began spy-hopping around the seal also. After 1-2 min of this, the entire group then either left the seal and resumed hunting, or initiated a wave-wash attack.

\section{Wave-Washing}

We observed 22 separate wave-wash attacks (Table 1), during which PI killer whales produced 120 individual waves. Preceding these attacks, individual whales ceased spy-hopping and began swimming together in a loose rank formation, rolling over at the surface, 2-7 animals abreast. Typically, after a couple of false starts, the whales swam off together, side-by-side at the surface, to a distance 5-50 m away before turning abruptly back toward the floe. As they charged underwater toward the floe, the whales converged, bodies parallel and almost touching, with their flukes beating rapidly and synchronously.

As they approached the floe below the surface, a small wave formed at the surface in front of their heads, followed by a deep trough above their tailstocks, and a second, larger wave above their pumping flukes. As they reached the ice edge, they lifted 


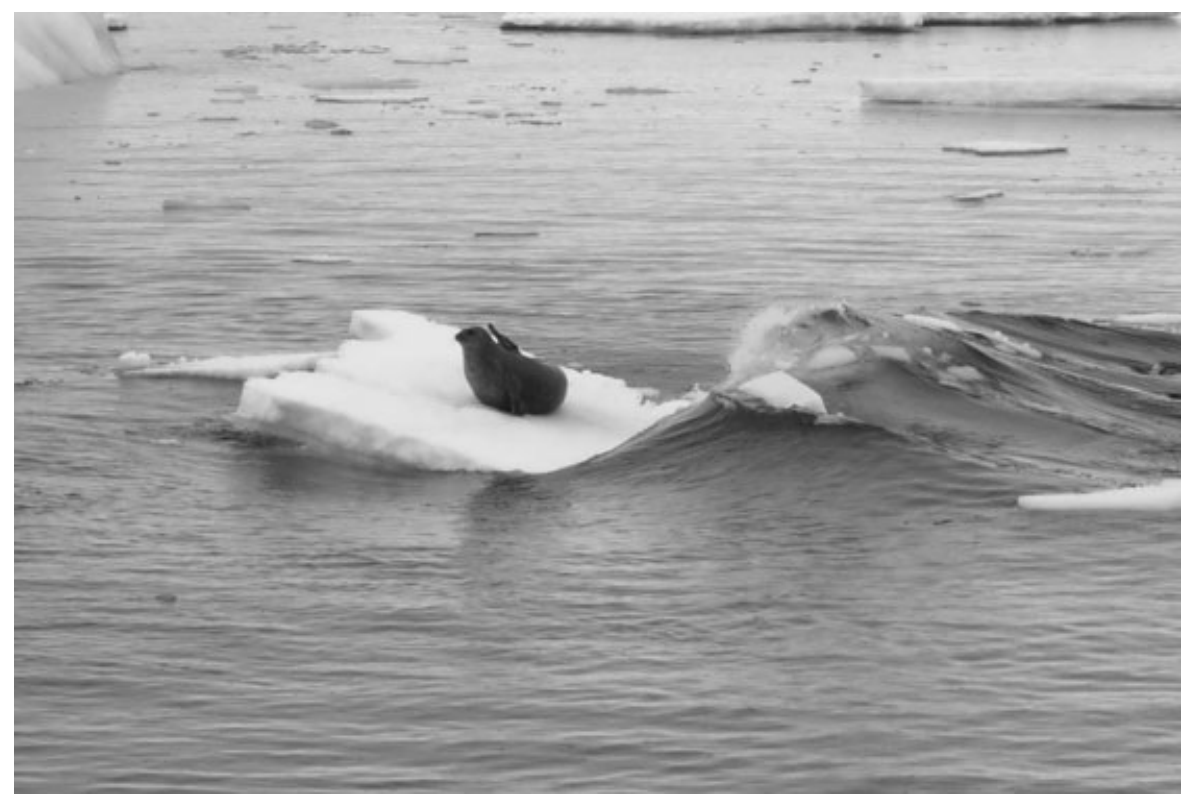

Figure 2. The wave shown here was generated by six pack ice killer whales (Table 1, Group 1, Event 1); the Weddell seal shown here was washed off the floe and eventually killed and eaten. The small floe is dipping into the trough immediately in front of the approaching ca. $1 \mathrm{~m}$ wave that washed completely over the floe. Notice the breaking peak of the wave directly in front of the seal. Photo: J. W. Durban.

their tails in one last power stroke, and the whole group dove under the ice, just barely avoiding contact with it. As they passed under the floe, the whales rolled a quarter turn on their sides, which prevented their dorsal fins from hitting the ice. Sometimes the entire group leaned in the same direction; at other times the group split down the middle with the animals on the right side leaning to the right, and those on the left leaning left.

The whales produced two distinct types of waves depending on the size of the floe. If the floe was small ( $c a .<5 \mathrm{~m}$ ), the whales usually created a wave that broke over the floe and often washed the seal(s) into the water. The typical height of breaking waves was about $1 \mathrm{~m}$ with the highest point being a cresting peak in the middle of the wave that appeared to be directed at the seal (Fig. 2). Smaller waves were sometimes generated by smaller subgroups (as few as two animals) of often younger whales, but these waves were largely ineffectual.

The second type of wave was a smaller, non-breaking wave that was used to break up larger floes. For that, the whales continued pumping their flukes underwater and carrying the wave with them as they passed under the full length of the floe. The result was that floes larger than about $5 \mathrm{~m}$ were usually shattered into smaller pieces (Fig. 3).

Regardless of floe size and wave type, most or all of the whales that created the wave swam rapidly under the floe to the opposite side, where they immediately turned around and spy-hopped in order to check on the seal (Fig. 3). If they succeeded in breaking up a large floe, they immediately moved in and began spy-hopping among 


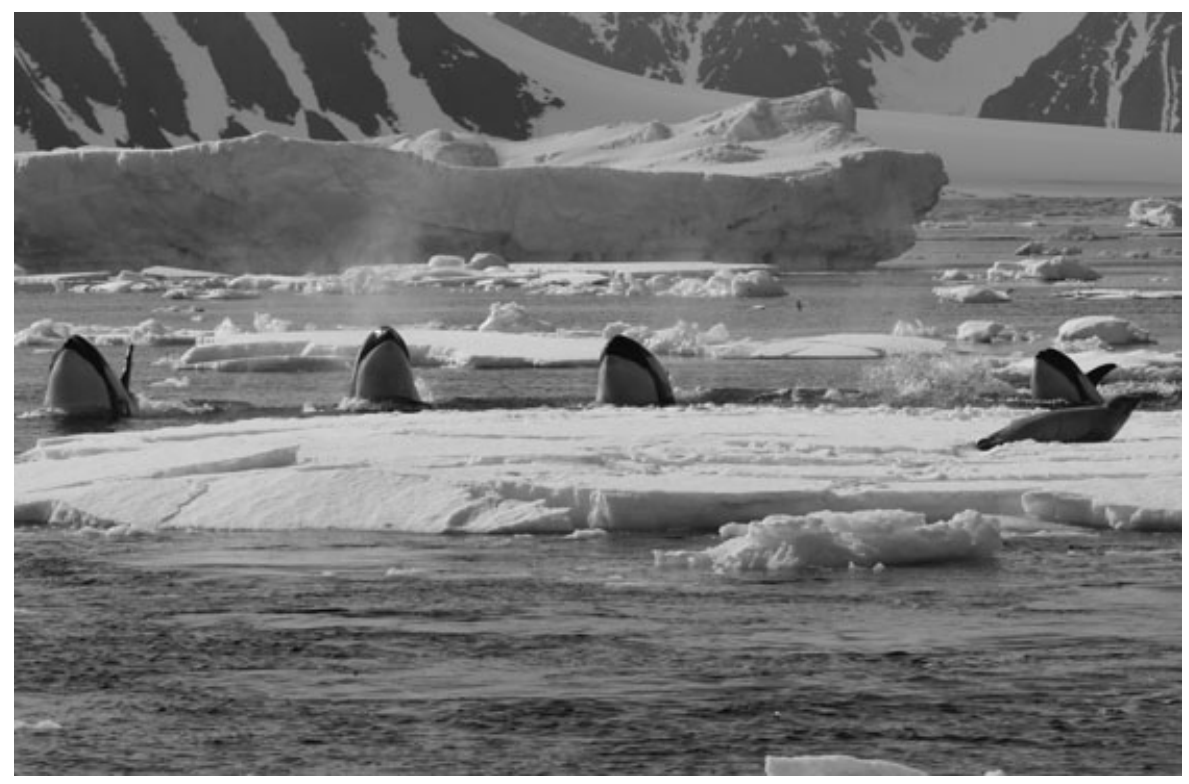

Figure 3. Part of a group of 10 pack ice killer whales (Table 1, Group 1, Event 2) that just swam under this $c a .20 \mathrm{~m}$ floe; the wave they generated as they passed beneath the ice shattered the floe-moments before it had been a single sheet of ice. Immediately on reaching the opposite side of the floe the whales turned and spy-hopped to relocate the seal. Photo: R. Pitman.

the broken pieces to locate the floe with the seal on it. On nine occasions we saw one or two whales (twice including a cow and calf) position themselves under a floe with a seal on it and use their rostrums to push it into open water. This repositioning left the seal more vulnerable to the next wave attack and kept it in open water if it was washed off. On two occasions, however, this effort simply caused the floe to spin with no net movement toward open water.

Although PI killer whales used wave-washing almost exclusively to drive seals off the ice, on three occasions, after several unsuccessful attempts to wave-wash seals wedged into irregularly shaped pieces of glacial ice, one or two whales positioned themselves beneath the ice and lifted it with their heads. On one occasion this resulted in flipping the ice over; on the other two occasions the ice broke, and in all three cases the seal was spilled into the water.

\section{Hunting Success and Prey Selectivity}

We recorded 17 separate predation events during which PI killer whales killed and ate 16 seals and 1 Antarctic minke whale. Of the 15 identified seals killed, 14 (93\%) were Weddell seals including 12 wave-washed off ice floes, one that was detected and taken in the water, and one taken in the water that may have been washed off a floe before we got to it. In addition, one southern elephant seal was also detected and taken in the water, and another, unidentified seal taken was of unknown provenance (Table 2). 
Table 2. Relative abundance of four different seal species during January 2009, in Laubeuf Fjord, Antarctica; predatory response of pack ice killer whales (Orcinus orca), type B, indicates a strong preference for Weddell seals (and possibly for much less common elephant seals).

\begin{tabular}{|c|c|c|c|c|c|}
\hline Seal species & $\begin{array}{l}\text { Our census } \\
\text { of seals } \\
\text { hauled out } \\
\text { on ice } \\
(n=365)\end{array}$ & $\begin{array}{c}\text { Killer whale } \\
\text { encounters with } \\
\text { seals on ice }(n= \\
\left.59^{\mathrm{a}}\right) / \text { total number } \\
\text { of seals present in } \\
\text { those encounters } \\
\left(n=108^{\mathrm{b}}\right)\end{array}$ & $\begin{array}{l}\text { Number of } \\
\text { seals washed } \\
\text { off the ice by } \\
\text { killer whales } \\
\quad\left(n=23^{b}\right)\end{array}$ & $\begin{array}{l}\text { Number of } \\
\text { seals killed } \\
\text { after wave- } \\
\text { washing } \\
(n=16)\end{array}$ & $\begin{array}{l}\text { Numbers of } \\
\text { seals killed } \\
\text { that were } \\
\text { first detected } \\
\text { in open } \\
\text { water } \\
(n=3)\end{array}$ \\
\hline $\begin{array}{l}\text { Southern } \\
\text { elephant }\end{array}$ & 0 & 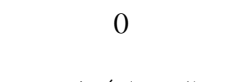 & 0 & 0 & 1 \\
\hline Crabeater & $299(82 \%)$ & $37 / 84(78 \%)$ & $5(14 \%)$ & 0 & 0 \\
\hline Weddell & $55(15 \%)$ & $17 / 19(18 \%)$ & $16(94 \%)$ & $12(75 \%)^{\mathrm{c}}$ & $1^{\mathrm{c}}$ \\
\hline Leopard & $11(3 \%)$ & $5 / 5(4 \%)$ & $1(20 \%)$ & 0 & 0 \\
\hline unidentified & - & - & - & - & $1^{\mathrm{d}}$ \\
\hline
\end{tabular}

aAn "encounter" was when one or more killer whales spy-hopped more than once at an ice floe where one or more seals were present; "\%" refers to total number of seals present ( $v$ s. encounters).

${ }^{\mathrm{b}}$ One event involved a crabeater and a Weddell on the same floe and is counted twice.

${ }^{\mathrm{c}}$ One Weddell seal, identified genetically from a tissue sample, was of unknown provenance and is not included here.

${ }^{\mathrm{d}}$ This seal may have been washed off an ice floe.

Wave-wash attacks that resulted in kills (when the launch was not in the water) lasted an average $30.4 \mathrm{~min}$ (range $15-62, n=7$ ), and the whales produced an average of 4.1 waves/attack (range $1-10, n=7$ ), an average of one wave every $7.3 \mathrm{~min}$. The groups of whales that we followed took a minimum of one seal every $4.9 \mathrm{~h}(73.5 \mathrm{~h} / 15$ seals), including seals that were initially encountered either on the ice or in the water; the number of seals taken per whale, per hour, stratified by group size had a median of 0.04 (range 0.01-0.09). This is probably an underestimate of their actual predation rate because, as mentioned above, attacking whales were sometimes distracted when our launch was in the water, and we may also have missed some kills.

The 16 separate wave-wash attacks on Weddell seals all resulted in the seals being washed into the water; of those, $12(75 \%)$ were killed and eaten and $4(25 \%)$ escaped. Of the four that escaped, one was a noticeably smaller seal that the whales abruptly left behind after a single wave attack. On the three other occasions, Weddell seals that were washed off floes subsequently swam to nearby bergy bits, and escaped because the whales could not dislodge them even after repeated attempts. Only once did we see whales deliberately pass up a Weddell seal on the ice, and it was hauled out on large piece of glacial ice that appeared to be too large for the whales to break up or wave-wash.

PI killer whales preyed upon Weddell seals almost exclusively although they were relatively uncommon. From our sample count of 365 seals identified on the ice, 299 $(82 \%)$ were crabeaters, $55(15 \%)$ were Weddells, and $11(3 \%)$ were leopards (Table 2). Spy-hopping whales encountered a similar species composition on the floes: of the 108 individual seals that we saw them detect on the ice on 58 separate occasions, 84 (78\%, in 37 groups) were crabeaters, 19 (18\%, in 17 groups) were Weddells and 
5 ( $4 \%$, in 5 groups) were leopard seals (Table 2). By contrast, of the 22 wave-wash attacks that we observed, $16(73 \%)$ targeted Weddell seals, $5(23 \%)$ were directed at crabeaters; and $1(4 \%)$ involved a young leopard seal (Table 1$)$. This meant that the whales attacked 94\% (16/17) of their Weddell seal encounters on the ice, 14\% $(5 / 37)$ of the crabeaters, and $20 \%(1 / 5)$ of the leopard seals (Table 2).

When seals other than Weddells were attacked, it appeared to be because the whales were initially unable to correctly identify the species. On six occasions, after PI killer whales wave-washed five separate crabeaters and one leopard seal into the water (Table 2), the whales approached the seals closely and then left them immediately. As a result, no crabeaters or leopard seals were killed or even physically harmed that we observed (Table 2). This also meant that whales spent less time when they attacked seals that were not Weddells (median duration $=8 \mathrm{~min}$, range $2-20, n=5$ ), vs. Weddells (median $=24 \mathrm{~min}$, range $2-62, n=10$; no launch in the water), and they also produced fewer waves when they attacked seals that were not Weddells (median number of waves $=1$, range $=1-4, n=6$ ), $v$ s. Weddells (median $=2$, range $=1-10$, $n=7$; no launch in the water). Also, on two occasions when whales encountered single leopard seals in the water, after a brief skirmish, the whales continued on their way and left the seal unharmed.

Antarctic fur seals were present in very small numbers during our study, and although the killer whales ignored them, the fur seals clearly perceived the whales as a threat. On two occasions, traveling PI killer whales passed closely by fur seals in the water and the fur seals suddenly bolted, porpoising out of the water, away from the whales, but the whales never changed their course.

One Antarctic minke whale was attacked and killed by a group of 10 killer whales that also regularly took Weddell seals (Group 1, Table 1). The small, probably juvenile, minke was alive and spouting blood when we first observed it at $0400 \mathrm{~h}$ but was dead 10 min later. It was probably killed when a large sub-adult male PI killer whale rammed it from below and hit it hard enough in the rear portion of the throat that the head of the minke was lifted out of the water. After the kill, the entire group fed on the carcass for $6.5 \mathrm{~h}$ before departing. Although minke whales were fairly common in Laubeuf Fjord, and sometimes passed within a few tens of meters of the killer whales, this was the only attack that we saw.

PI killer whales interacted with humpback whales on at least five occasions, but we saw no serious or sustained attacks. When two PI killer whales (a subadult male and an adult female; Group 1, Table 1) broke off from their group to harass an adult humpback for several minutes it tail-slapped vigorously and "trumpeted" (bellowed) loudly and the killer whales departed. On three other occasions, 2-4 adult-sized humpback whales appeared to deliberately disrupt PI killer whales that were attacking seals on ice floes (Pitman and Durban 2009).

In addition to marine mammals, Adélie penguins were also fairly common in the area, but we saw no whale interactions with them.

\section{Prey Handling and Feeding Behavior on Weddell Seals}

When Weddell seals were washed into the water ( $n=49$ times), they usually responded to attacking whales by either swimming away to a nearby floe $(n=11$, $22 \%)$, or, most often, by immediately climbing back out on to the same ice floe ( $n=$ $26,53 \%)$. On the remaining occasions $(n=12,24 \%)$ the target seals were caught and killed by the whales as they tried to either swim away or climb back out on 
the floe. Whenever a targeted Weddell seal crawled back out on a floe, the whales resumed wave-washing almost immediately, sometimes after pushing the floe out into open water.

Initially, the seals were very aggressive, especially when they were in the water, and the whales stayed at least a meter away from the seals' exposed teeth and snapping jaws. When a seal was in the water, the whales usually worked as a group and took turns trying to move it away from the floe. One or more whales would make fast passes by the seal, jostling it with their wake and churning the water with their flukes as they passed within a meter or so. Individual whales sometimes exhaled large amounts of air through their blowhole near or under the seal in what appeared to be an attempt to confuse or frighten it with the bubbles. From one to five individual whales would sometimes move in close to the seal and hang almost vertically in the water, just looking at it.

Whenever a seal was washed into the water, one of the attacking whales usually attempted to take the seal's hind flippers in its mouth and pull it down below the surface, and it appeared that the overall goal was to tire the seal and drown it. Seals in the water quickly learned, or instinctively knew, that the whales were targeting their hind flippers because when a seal was attacked next to a floe, usually it almost immediately began "standing on its head," waving its rear flippers in the air, presumably to keep them away from the whales and to face their attackers. Several times we also saw whales pull seals off the ice if their flippers were hanging off the edge of the floe and in every case the whales took only the very tips of the flippers in their mouth, even if a substantial part of the hindquarters was exposed.

During the attacks, we often saw clearly exhausted seals in open water that the much larger whales could easily have dispatched with a single bite or ram, but in every case the killer whales continued to carefully pull them underwater by the hind flippers. Except for some minor lacerations to the mid-section and some bloodied knuckles on the hind flippers, we saw very little injury to the seals before they were killed and normally the seal just quietly disappeared with little or no visible blood.

About the time that it became clear (to us) that the seal was tiring and beginning to lose the struggle, some of the whales in the group apparently started losing interest and began spy-hopping again around nearby floes. Usually by the time the kill actually happened, most of the group was off looking for more seals. At about this time, the seal was taken down one last time and not seen alive again.

After each of the 12 wave-wash kills that we observed, the seal was carried off from the kill site, approximately 100-500 m, before it was consumed. Although on one occasion the entire group moved off $c a .100 \mathrm{~m}$ after a kill and began to feed immediately, usually most of the group resumed hunting (i.e., traveling and spy-hopping), while one or two whales followed behind, carrying the carcass and, perhaps, preparing it for feeding (see below). After about 5-10 min, we assumed that the whale(s) carrying the carcass sent out a vocal signal because the rest of the group quickly came back and joined them and began to feed. At this time whales began diving in one location, arching their backs high out of the water as they sounded. Calves and juveniles, in particular, apparently became excited: they swam around rapidly at the surface, changing directions often, lifting their heads out of the water and regularly arching over for deep dives also.

When the killer whales dismembered their mammalian prey underwater, an oil slick with a strong fishy odor usually formed at the surface. Near Adelaide Island, this odor usually attracted flocks of dozens of Wilson's storm-petrels (Oceanites oceanicus), which hovered over the slick and fed on oil droplets and bits of tissue. Whenever the 
whales began wave-washing a floe with a seal on it, they usually attracted as many as several dozen brown skuas (Stercorarius antarctica), which roosted on nearby floes until the whales began feeding; then when a slick appeared they began searching for scraps to scavenge. At that time, feeding whales, especially juveniles, were sometimes seen swimming at or just below the surface with flesh in their mouths. Sometimes, adult females that were stationary at the surface were seen to shudder as a juvenile or calf worked next to their head-twice when we saw this happen, the pair was seen to be pulling apart a piece of flesh.

Prey sharing seemed to be the norm after each kill. All group members were usually involved in the feeding, and we never saw any overt signs of aggression or even tussling. This apparent cooperative feeding occurred not only within groups but sometimes between groups as well. For example, Group 2 participated in wavewashing with Groups 1 and 3 at different times (Table 1) and shared the seal kills afterwards.

Normally we saw only small scraps of the prey at the surface once the whales started feeding, but on 30 January we examined some Weddell seal remains that floated to the surface minutes after a kill that we had witnessed, and it provided evidence that the whales had methodically dismembered the carcass in order to feed on it. The remains weighed an estimated $45 \mathrm{~kg}$ and consisted of a single piece of skin and blubber from the entire anterior portion of the body, including the fore flippers, shoulder blades (clavicles) and head (Fig. S1). The skin and blubber had been cut completely around the lower body on a transverse plane in about the area of the hips. Parallel lacerations on the skin indicated where a whale had apparently used its teeth to pull the skin and blubber toward the head to strip it off the carcass, presumably while another whale pulled in the opposite direction on the lower portion of the body. Both foreflippers had been cleanly disarticulated at the ball and socket joint at the proximal end of each humerus without breaking any bones. There was also a clean (i.e., not ragged) transverse tear in the skin at the back of the neck and the skin had been reflected forward over the top of the head, exposing the otherwise intact skull (Fig. S1). This allowed access to the spine, which had been cleanly separated from the skull at the first cervical vertebra (atlas), with no apparent damage to the skull or the skin on the head (Fig. S2). Processing the carcass like this would have allowed the whales to slide almost the entire body out of the skin, intact and in one piece.

\section{DISCUSSION}

\section{Hunting Behavior}

PI killer whales wave-washing seals off ice floes is more common and widespread in Antarctica than previous records would suggest. Prior to this study, wave-washing had been documented on only five separate occasions and all within a $61 \mathrm{~km}$ segment off the west coast of the AP (Visser et al. 2008), suggesting that it might be a rare or localized behavior. However, the three groups of PI killer whales that we observed hunted almost exclusively by wave-washing, attacking a minimum of 22 different seals over the $12 \mathrm{~d}$ period, an average of one wave-wash attack every $3.3 \mathrm{~h}$ during the time we were with them. And although our sightings extend the known geographic range of this behavior by 250 linear kilometers to the south, there is evidence that it may be substantially more widespread. Pierpont (1996) described an incident where three killer whales (identified in a video as PI killer whales; RLP, 
personal observation) approached a launch and spy-hopped several times within a few meters of it; they then swam approximately $30 \mathrm{~m}$ away, turned and swam directly at the boat and created a wave that nearly washed passengers over the side. This incident occurred approximately $3,500 \mathrm{~km}$ west of Adelaide Island, suggesting that wave-washing behavior is widespread in Antarctica and may occur around the entire continent.

Although whales and dolphins in general have fairly good visual acuity out of the water (Mass and Supin 2009), PI killer whale is the only cetacean known that regularly detects and captures prey out of the water. It was clear, however, that they sometimes had difficulty distinguishing among the different seal species on the floes, even after spy-hopping around them numerous times. Most large floes needed to be broken up so that the whales could move in for a closer look, and even seals on small floes sometimes had to be washed into the water so the whales could approach and identify them. As a result, although no leopard seals or crabeaters were harmed during our study, they were "attacked" on six occasions (Table 2).

The whales were noticeably cautious about the way they captured and killed seals, and initially we suspected that they were just trying to avoid being bitten because seals regularly snapped at them when they approached too closely. But even when the seals were exhausted by the attacks and barely able to crawl out on the ice and could seemingly easily and safely have been dispatched with a single bite, the whales continued to take them by just the tips of their hind flippers and drag them below the surface. We suggest that the whales wanted to wear out the seals by repeatedly dragging them underwater, and then drown them so that there was minimal damage to the carcass. This would have made it easier for the whales to separate the skin and blubber from the body as described earlier.

The seal kills that took place entirely in the water were very rapid compared to seals wave-washed off ice floes $(<5 \mathrm{~min} v$ s. $30 \mathrm{~min})$, and it was not clear why the whales preferred to hunt seals on floes instead of just searching for them in open water. It could be because Weddell seals are more commonly encountered on the ice during the day (Plötz et al. 2001), allowing more reliable opportunities for detection and capture.

Compared to mammal-eating killer whales in the northeast Pacific, PI killer whales showed both similarities and differences in the way that they killed their prey. Mammal-eating "transients" often dispatch (or at least wear down) pinnipeds by swatting them with their tails, leaping out of the water and landing on them, or butting them with their heads (Baird and Dill 1995, Ford et al. 1998) — to date, none of these behaviors has been reported for PI killer whales taking seals. It may be that hunting different pinniped species requires different tactics, or it could also be that pinniped hunting evolved independently and divergently within these two killer whale lineages. However, the minke whale that we saw taken was apparently killed when an subadult male PI killer whale rammed it from below, a tactic commonly used by transient killer whales in the North Pacific for taking common minke whales (Balaenoptera acutorostrata) (Ford et al. 2005) and gray whales (Eschrichtius robustus) (Melnikov and Zagrebin 2005; Barrett-Lennard et al., in press).

One of the most distinctive morphological features of PI killer whales is their very large postocular eye patch (Pitman and Ensor 2003). Although the selective forces driving the development of this feature cannot be known for certain, having a large, conspicuous eye patch is potentially very useful for visually coordinating wavewashing behavior when groups swim rapidly in a tightly synchronized formation. In close quarters, with animals practically touching each other, normal acoustic 
communication might not be as effective as having a conspicuous visual landmark, especially in the fairly turbid waters where our observations occurred.

\section{Prey of PI Killer Whales}

Our observations confirm that PI killer whales prey primarily on ice seals when in the Antarctic pack ice, but there is evidence to suggest that their hunting habits and diet may be considerably more diverse depending on a number of factors including season, location, prey availability and perhaps even body condition of the whales.

Although they avoided crabeaters and leopard seals during our study, PI killer whales are known to take them at times (Visser et al. 2008, see also later). And in addition to Weddell seal, southern elephant seal may also be a preferred, but less common prey species. The only elephant seal that we identified in Laubeuf Fjord was the one that was killed and eaten, and the only other seal we had previously seen taken by PI killer whales in Antarctic waters was also an elephant seal (Pitman and Ensor 2003).

In addition to preying on seals, there are at least two unconfirmed reports of PI killer whales "attacking" Antarctic fur seals in the AP area (Dalla Rosa et al. 2007), but during our study PI killer whales passed up at least two easy opportunities to attack fur seals and then went on to kill and eat Weddell seals shortly afterward. Furthermore, during our 2010 season in the Gerlache Strait, we regularly saw fur seals swimming alongside and apparently hunting (or perhaps scavenging) with PI killer whales-behavior that could easily have been misinterpreted as an attack. More observations will be needed to determine to what extent and under what conditions PI killer whales prey upon other pinniped species.

Cetaceans are also potentially important prey species for PI killer whales, but documentation is lacking. Although our observation is the first confirmed kill of an Antarctic minke whale of which we are aware, tour vessels operating in the Peninsula area regularly report killer whales purportedly attacking minke whales, although in every case that we have reviewed predation was not confirmed, or the killer whales involved were type A or not assignable to type. Tour ships have also reported PI killer whales "harassing" humpback whales and we have seen this on occasion also (see section "Results"), but healthy adult humpbacks do not seem to be threatened by killer whales, and in fact humpbacks at times seem to initiate aggressive interactions with killer whales (Pitman and Durban 2009). PI killer whales were also photographed harassing fin whales (Balaenoptera physalus) for over $1.5 \mathrm{~h}$ at Shag Rocks, west of South Georgia in what may have been an attack. ${ }^{2}$ The fact that PI killer whales regularly approach rorquals, apparently to test them, suggests that these advances probably result in successful predation events at times, and that cetaceans, especially their calves, could be important prey species ( $c f$. Mehta et al. 2007).

In addition to mammalian prey, "type B" killer whales in the Gerlache Strait were recently reported feeding on pygoscelid penguins (Pitman and Durban 2010). However, there appears to be at least two different forms of type B killer whales in the Peninsula area, including a large form that wave-washes seals off ice floes (PI killer whale), and a smaller form with unknown prey preferences that takes penguins

\footnotetext{
${ }^{1}$ Personal communication from Jérôme Poncet, Beaver Island, P. O. Stanley, Falkland Islands, January 2009.

${ }^{2}$ Personal communication from Todd Pusser, 126 Michael Lane, Aberdeen, NC 28315, May 2009.
} 
at times (Pitman and Durban 2010). In order to assess the trophic impact of killer whales in Antarctic waters, it will be necessary to determine not only the feeding habits and relative abundance of the different ecotypes that comprise that community, but to resolve their phylogenetic relationships as well (Morin et al. 2010).

Additional, indirect evidence that PI killer whales probably take other prey and have other hunting behaviors comes from satellite-tagged individuals from two different groups that we tracked from Adelaide Island (Groups 2 and 3; Table 1). They left the Peninsula area and traveled north through the Drake Passage on what may have been a northbound migration ${ }^{3}$ making it possible that PI killer whales spend a significant part of the year in areas far removed from sea ice and ice seals. PI killer whales have also been photographed associated with longline fishing vessels operating off the Falkland Islands and South Georgia where Patagonian toothfish (Dissostichus eleginoides) were being depredated, so they may also feed on fish at times. $^{3}$

These observations suggest that prey choice for this "seal specialist" may be more facultative than previously recognized, depending on local and seasonal abundance of available prey and the seasonal movements of PI killer whales as has been suggested for other killer whale "ecotypes" (Foote et al. 2009).

\section{Prey Selectivity and Prey Handling}

As known predators of crabeater and leopard seals (Pitman and Ensor 2003, Visser et al. 2008), PI killer whales' near-exclusive preference for Weddell seals during this study was unexpected. When PI killer whales encountered Weddell seals on ice they attacked 16 out of 17 times (94\%), but when they encountered crabeaters or leopard seals they attacked only 6 out of 42 times (14\%; Table 2). And on the six occasions when they did attack crabeaters or leopard seals, it appeared that the whales were initially either uncertain about the species of the seal or misidentified them, because in every case, after they inspected the seal(s) more closely, they left them behind, unharmed.

This degree of species-specific prey preference has not previously been reported for mammal-eating killer whales, although it has been documented among fisheaters. In the northeast Pacific, "resident" killer whales take mostly chinook salmon (Oncorbynchus tshawytscha) among the six species of salmon available to them, even though it is often one of the least abundant salmon species present (Ford et al. 1998, Ford and Ellis 2006, Ford et al. 2010, Hanson et al. 2010). Those authors speculated that chinook was specifically targeted because of its larger size and higher fat content. Interestingly, fish-eating killer whales in Prince William Sound, Alaska, also target one species of salmon, but the preferred species there is coho (0. kisutch; Saulitis et al. 2000).

The PI killer whale prey selectivity that we observed may have included not only the species of seal that they took but also the parts of the seal that they consumed. When prey is abundant killer whales tend to consume only specific parts of individual prey. For example, when whale carcasses were made available during historical whaling operations or when gray whale (Eschrichtius robustus) calves are killed during northbound migration, killer whales often eat only the lips and tongues (Jefferson et al. 1991; Ford et al. 2005; Melnikov and Zagrebin 2005; Barrett-Lennard et al., in press). And this can apply to very small prey as well: killer whales that fed on

\footnotetext{
${ }^{3}$ Durban and Pitman, unpublished data.
} 
the 4-6 kg pygoscelid penguins in Antarctica sometimes ate only the breast muscles and discarded the rest of the carcass (Pitman and Durban 2010).

This could be considered a form of "surplus killing" (Kruuk 1972) and may apply to pinniped prey also. For example, Heise et al. (2003) reported that stranded mammal-eating killer whales in Alaska sometimes had harbor seal (Phoca vitulina) skin in their stomachs, but that feeding whales sometimes removed the skin from harbor seals and discarded it before eating them. Although we were able to examine the remains of only one Weddell seal taken by PI killer whales, it was so meticulously dismembered (a process perhaps best termed "butchering") that we infer that the whales ate only certain parts of it. It is important to know how much of individual prey items killer whales actually consume because the less of the individual prey that they eat, the more they will have to kill to sustain their metabolic needs (Williams et al. 2004).

During times of food abundance animals are expected to be more selective in their feeding habits (e.g., Baird and Dill 1996, Chen et al. 2004), and we suggest that the prey selectivity that PI killer whales showed for certain parts of certain seal species may have been related to seasonal feeding success and body condition of the whales. As mentioned above, at least two of the three groups that we satellitetracked abruptly left the Peninsula area within a week of tagging and crossed the Drake Passage on what may have been a northbound migration. ${ }^{4}$ Also, an adult male in one of the tagged groups was the fattest killer whale we have ever seen in the wild. This raises the possibility that these whales may have been "topping off' after a successful summer feeding season in Antarctica and had, consequently, become more selective in their feeding. There is also evidence that there may be times when these whales are not so selective about their prey preferences. We recently examined a photograph that was taken in the Gerlache Strait during June 2010; it shows whales from our Group 3 (Table 1) including one spy-hopping and holding a crabeater seal crosswise in its mouth that was subsequently killed and eaten. ${ }^{5}$

The degree to which PI killer whales preferentially target Weddell seals could have important ecological implications for both species. If the whales prove to be as dependent upon Weddell seals as resident killer whales are on Chinook salmon in the northeast Pacific (Ford et al. 2010), then the overall hunting success and, ultimately, survival of the whales could be at stake. Conversely, selective predation by killer whales could already be having an impact on Weddell seal populations. Currently, Weddell seal numbers are declining in the AP region, and although climate warming and commercial overfishing of their prey have been suggested as possible drivers (Siniff et al. 2008, Ainley and Blight 2009, Ainley and Siniff 2009), killer whale predation must now also be considered a contributing and potentially significant factor. More observations, from different times of the year and involving individuals with known feeding histories, will be necessary to fully understand the extent and ecological significance of prey selectivity by PI killer whales in Antarctica.

\section{ACKNOWLEDGMENTS}

J. Poncet and D. Poncet helped with shipboard operations and BBC personnel on the Frozen Planet film crew-D. Alan, D. Anderson, and K. Jeffs-allowed us to work on the boat with

\footnotetext{
${ }^{4}$ Durban and Pitman, unpublished data.

${ }^{5}$ Personal communication from Ari Friedlaender, Assistant Research Scientist, Duke University Marine Laboratory, 135 Pivers Island Road, Beaufort, NC 28516, July 2010.
} 
them during their filming; all were generous with their time and enthusiasm for our project. Satellite tags were purchased from a grant by the National Geographic Society. We thank C. Pierpoint and J. Frizell of Greenpeace International for sharing their descriptions and video, respectively, of the McMurdo wave-wash event. O. Carlsson, J. Drennan, A. Friedlaender, J. Poncet, and T. Pusser provided details about their killer whale observations from the Peninsula area; Y. Ivashchenko translated Soviet papers for us, and H. Fearnbach provided field assistance. We had informative discussions about seal biology and identification with D. Siniff, B. Stewart, I. Stirling, and T. Smith and our paper was improved by the comments of R. Baird, L. Ballance, W. F. Perrin, D. Siniff, and two anonymous reviewers. K. Robertson at the Marine Mammal Genetics Laboratory at Southwest Fisheries Science Center, La Jolla, genetically confirmed the identification of two of our seal tissue samples. All research was conducted under ACA Permit No. 2009-013M\#1, and MMPA No. 774-1714-08 issued to NOAA Fisheries, Southwest Fisheries Science Center.

\section{Literature Cited}

Ainley, D. G., and L. K. Blight. 2009. Ecological repercussions of historical fish extraction from the Southern Ocean. Fish and Fisheries 10:13-38.

Ainley, D. G., and D. B. Siniff. 2009. The importance of Antarctic toothfish as prey of Weddell seals in the Ross Sea. Antarctic Science 21:317-327.

Ainley, D. G., G. Ballard, S. Ackley, et al. 2007. Paradigm lost, or, is top-down forcing no longer significant in the Antarctic marine ecosystem? Antarctic Science 19:283290.

Ainley, D., G. Ballard, L. K. Blight, et al. 2009. An apparent decrease in the prevalence of "Ross Sea killer whales" in the southern Ross Sea. Aquatic Mammals 35:335347.

Ainley, D., G. Ballard, L. K. Blight, et al. 2010. Impacts of cetaceans on the structure of Southern Ocean food webs. Marine Mammal Science 26:482-498.

Andrews, R. D., R. L. Pitman and L. T. Ballance. 2008. Satellite tracking reveals distinct movement patterns for Type B and Type C killer whales in the southern Ross Sea, Antarctica. Polar Biology 31:1461-1468.

Baird, R. W., and L. M. Dill. 1995. Occurrence and behaviour of transient killer whales: Seasonal and pod-specific variability, foraging behaviour, and prey handling. Canadian Journal of Zoology 73:1300-1311.

Baird, R. W., and L. M. Dill. 1996. Ecological and social determinants of group size in transient killer whales. Behavioral Ecology 7:408-416.

Barbraud, C., and C. Cotté. 2008. Paradigms need hypothesis testing: No evidence for topdown forcing on Adélie and emperor penguin populations. Antarctic Science 20:391392.

Barrett-Lennard, L. G., C. O. Matkin, J.W. Durban, E. L. Saulitis and D. K. Ellifrit. In press. Gray whale predation and prolonged feeding on submerged carcasses by transient killer whales at Unimak Pass, Alaska. Marine Ecology Progress Series.

Bolt, H. E., P. V. Harvey, L. Mandleberg and A. D. Foote. 2009. Occurrence of killer whales in Scottish inshore waters: Temporal and spatial patterns relative to the distribution of declining harbour seal populations. Aquatic Conservation: Marine Freshwater Ecosystem 19:671-675.

Branch, T.A., and T. M. Williams. 2006. Legacy of industrial whaling: Could killer whales be responsible for declines of sea lions, elephant seals, and minke whales in the Southern Hemisphere? Pages 262-278 in J. A. Estes, D. P. DeMaster, D. F. Doak, T. M. Williams and R. L. Brownell, eds. Whales, whaling and ocean ecosystems. University of California Press, Berkeley, CA.

Chen, X., C. R. Dickman and M. B. Thompson. 2004. Selective consumption by predators of different body regions of prey: Is rate of energy intake important? Journal of Zoology, London 264:189-196. 
Clapham, P. J. 2001. Why do baleen whales migrate? A response to Corkeron and Connor. Marine Mammal Science 17:432-436.

Connor, R. C., and P. J. Corkeron. 2001. Predation past and present: Killer whales and baleen whale migration. Marine Mammal Science 17:436-439.

Corkeron, P. J., and R. C. Connor. 1999. Why do baleen whales migrate? Marine Mammal Science 15:1228-1245.

Dalla Rosa, L., M. Bassoi, E. R. Secchi, D. Danilewicz, I. B. Moreno, M. C. O. Santos and P. A. C. Flores. 2007. Occurrence and distribution of killer whales in the waters of the Antarctic Peninsula. Paper SC/59/SM10 presented to the IWC 59th Scientific Committee, May 2007, Anchorage, AK. 6 pp.

DeMaster, D. P., A. W. Trites, P. Clapham, S. Mizroch, P. Wade and R. J. Small. 2006. The sequential megafaunal collapse hypothesis: Testing with existing data. Progress in Oceanography 68:329-342.

Estes, J. A., M. T. Tinker, T. M. Williams and D. F. Doak. 1998. Killer whale predation on sea otters linking oceanic and nearshore ecosystems. Science 282:473-476.

Estes, J. A., D. F. Doak, A. M. Springer and T. M. Williams. 2009. Causes and consequences of marine mammal population declines in southwest Alaska: A food-web perspective. Philosophical Transactions of the Royal Society, B 364:1647-1658.

Foote, A. D., J. Newton, S. B. Piertney, E. Willerslev and M. T. P. Gilbert. 2009. Ecological, morphological and genetic divergence of sympatric North Atlantic killer whale populations. Molecular Ecology 18:5207-5217.

Ford, J. K. B., and G. M. Ellis. 2006. Selective foraging by fish-eating killer whales Orcinus orca in British Columbia. Marine Ecology Progress Series 316:185-199.

Ford, J. K. B., G. M. Ellis, L. Barrett-Lennard, A. B. Morton, R. Palm and K. C. Balcomb. 1998. Dietary specialization in two sympatric populations of killer whales (Orcinus orca) in coastal British Columbia and adjacent waters. Canadian Journal of Zoology 76:1456-1471.

Ford, J. K. B., G. M. Ellis and K. C. Balcomb. 2000. Killer whales: The natural history and genealogy of Orcinus orca in British Columbia and Washington State. 2nd edition. University of British Columbia Press, Vancouver, Canada.

Ford, J. K. B., G. M. Ellis, D. R. Matkin, K. C. Balcomb, D. Briggs and A. B. Morton. 2005. Killer whale attacks on minke whales: Prey capture and antipredator tactics. Marine Mammal Science 21:603-618.

Ford, J. K. B., G. M. Ellis, P. F. Olesiuk and K. C. Balcomb. 2010. Linking killer whale survival and prey abundance: Food limitation in the oceans' apex predator? Biology Letters 6:139-142.

Forney, K. A., and Wade, P. 2006. Worldwide distribution and abundance of killer whales. Pages 145-162 in J. A. Estes, R. L. Brownell, D. P. DeMaster, D. F. Doak and T. M. Williams, eds. Whales, whaling and ocean ecosystems. University of California Press, Berkeley, CA.

Guinet, C., P. Jouventin and H. Weimerskirch. 1992. Population changes, movements of southern elephant seals in Crozet and Kerguelen Archipelagos in the last decades. Polar Biology 12:349-356.

Hanson, M. B., R. W. Baird, J. K. B. Ford, et al. 2010. Species and stock identification of prey consumed by endangered southern resident killer whales in their summer range. Endangered Species Research 11:69-82.

Heise, K., L. G. Barrett-Lennard, E. Saulitis, C. Matkin and D. Bain. 2003. Examining the evidence for killer whale predation on Steller sea lions in British Columbia and Alaska. Aquatic Mammals 29:325-334.

Jefferson, T. A., P. J. Stacey and R. W. Baird. 1991. A review of killer whale interactions with other marine mammals: Predation to co-existence. Mammal Review 21:151180.

Kruuk, H. 1972. Surplus killing by carnivores. Journal of Zoology 166:233-244. 
LeDuc, R. G., K. M. Roberston and R. L. Pitman. 2008. Mitochondrial sequence divergence among Antarctic killer whale ecotypes is consistent with multiple species. Biology Letters 4:426-429.

Mass, A. M., and A. Y. Supin. 2009. Vision. Pages 1200-1211 in Encyclopedia of marine mammals. 2nd edition. W. F. Perrin, B. Würsig and J. G. M. Thewissen, eds. Elsevier, San Diego, CA.

Mehta, A. V., J. M. Allen, R. Constantine, et al. 2007. Baleen whales are not important as prey for killer whales Orcinus orca in high-latitude regions. Marine Ecology Progress Series 348:297-307.

Melnikov, V. V., and I. A. Zagrebin. 2005. Killer whale predation in coastal waters of the Chukotka Peninsula. Marine Mammal Science 21:550-556.

Mizroch, S. A., and D. W. Rice. 2006. Have North Pacific killer whales switched prey species in response to depletion of the great whale populations? Marine Ecology Progress Series 310:235-246.

Morin, P. A., F. I. Archer, A. D. Foote, et al. 2010. Complete mitochondrial genome analysis of killer whales (Orcinus orca) indicates multiple species. Genome Research 20:908-916.

Pierpoint, C. 1996. Observations of (and by!) killer whales in Antarctica. Soundings [Newsletter of the SeaWatch Foundation] 2:1-3.

Pitman, R. L., and J. W. Durban. 2009. Save the seal! Natural History Magazine 11/09:48.

Pitman, R. L., and P. Ensor. 2003. Three different forms of killer whales in Antarctic waters. Journal of Cetacean Research and Management 5:131-139.

Pitman, R. L., and J. W. Durban. 2010. Killer whale predation on penguins in Antarctica. Polar Biology 33:1589-1594.

Plötz, J., H. Bornemann, R. Knust, A. Schröder and M. Bester. 2001. Foraging behavior of Weddell seals, and its ecological implications. Polar Biology 24:901-909.

Saulitis, E., C. Matkin, K. Heise, L. Barrett-Lennard and G. Ellis. 2000. Foraging strategies of sympatric killer whale (Orcinus orca) populations in Prince William Sound, Alaska. Marine Mammal Science 6:94-109.

Siniff, D. B., R. A. Garrott, J. J. Rotella, W. R. Fraser and D. G. Ainley. 2008. Opinion: Projecting the effects of environmental change on Antarctic seals. Antarctic Science 20:425-432.

Smith, T. G., D. B. Siniff, R. Reichle and S. Stone. 1981. Coordinated behavior of killer whales, Orcinus orca, hunting a crabeater seal, Lobodon carcinophagus. Canadian Journal of Zoology 59:1185-1189.

Springer, A. M., J. A. Estes, G. B. van Vliet, et al. 2003. Sequential megafaunal collapse in the North Pacific Ocean: An ongoing legacy of industrial whaling? Proceedings of the National Academy of Sciences 100:12223-12228.

Springer A. M., J. A. Estes, G. B. van Vliet, et al. 2008. Mammal-eating killer whales, industrial whaling, and the sequential megafaunal collapse in the North Pacific Ocean: A reply to critics of Springer et al. 2003. Marine Mammal Science 24:414-442.

Trites, A. W., V. B. Deecke, E. J. Gregr, J. K. B. Ford and P. F. Olesiuk. 2007. Killer whales, whaling and sequential megafaunal collapse in the North Pacific: A comparative analysis of the dynamics of marine mammals in Alaska and British Columbia following commercial whaling. Marine Mammal Science 23:751-765.

Visser, I. N., T. G. Smith, I. D. Bullock, G. D. Green, O. G. L. Carlsson and S. Imberti. 2008. Antarctic peninsula killer whales (Orcinus orca) hunt seals and a penguin on floating ice. Marine Mammal Science 24:225-234.

Wade, P. R., V. N. Burkanov, M. E. Dahlheim, et al. 2007. Killer whales and marine mammal trends in the North Pacific-A re-examination of evidence for sequential megafauna collapse and the prey-switching hypothesis. Marine Mammal Science 23:766-802.

Wade, P. R., J. M. ver Hoef and D. P. DeMaster. 2009. Mammal-eating killer whales and their prey-Trend data for pinnipeds and sea otters in the North Pacific Ocean do not support the sequential megafaunal collapse hypothesis. Marine Mammal Science 25:737-747. 
Williams, T. M., J. A. Estes, D. F. Doak and A. M. Springer. 2004. Killer appetites: Assessing the role of predators in ecological communities. Ecology 85:3373-3384.

Received: 15 February 2010

Accepted: 17 November 2010

\section{SUPPORTING INFORMATION}

Additional Supporting Information may be found in the online version of this article:

Figure S1. Remains of a Weddell seal killed by pack ice killer whales (Table 1, Group 3, Event 21) near Adelaide Island, Antarctica, 30 January 2009. Shown here is the intact skin and blubber from the entire upper body after the whales removed the axial body (except for the skull) and posterior extremities. The sets of parallel dark lines on the lower part of the skin are killer whale tooth rake marks. The arrow points to the top of the exposed skull — the whales slit the skin along the back of the neck and pulled it forward over the back of the head, exposing the anterior spinal column and skull. Photo: K. Jeffs.

Figure S2. The head of the same Weddell seal from Figure S1 after we pulled the skin back into position to show that the head was undamaged during the kill and subsequent "butchering" process. The skin was cut behind the neck and reflected forward apparently to expose the spine so that it could be disarticulated from the base of the skull (see text). Photo: K. Jeffs. 